\title{
Front Matter: Volume 11904
}

, "Front Matter: Volume 11904," Proc. SPIE 11904, Plasmonics VI, 1190401 (2 November 2021); doi: 10.1117/12.2618926

SPIE. Event: SPIE/COS Photonics Asia, 2021, Nantong, Jiangsu, China 


\title{
PROCEEDINGS OF SPIE
}

\section{Plasmonics VI}

\author{
Zheyu Fang \\ Takuo Tanaka \\ Editors
}

\section{0-12 October 2021 \\ Nantong, China}

Sponsored by

SPIE

COS-Chinese Optical Society

Cooperating Organizations

Tsinghua University (China) • Peking University (China) • University of Science and Technology of China (China)

- Zhejiang University (China) • Tianjin University (China) • Beijing Institute of Technology (China) • Beijing

University of Posts and Telecommunications (China) • Nankai University (China) $\bullet$ Changchun University of Science and Technology (China) • University of Shanghai for Science and Technology (China) • Capital Normal University (China) • Huazhong University of Science and Technology (China) • Beijing Jiaotong University (China) • China Jiliang University (China) • Shanghai Institute of Optics and Fine Mechanics, CAS (China) • Changchun Institute of Optics, Fine Mechanics and Physics, CAS (China) • Institute of Semiconductors, CAS (China) • Institute of Optics and Electronics, CAS (China) • Institute of Physics, CAS (China) • Shanghai Institute of Technical Physics, CAS (China) • China Instrument and Control Society (China) - The Optical Society of Japan (Japan) - Optical Society of Korea (Korea, Republic of) - Australia and New Zealand Optical Society (Australia) - Optics and Photonics Society of Singapore (Singapore) • European Optical Society

\section{Supporting Organizations}

China Association for Science and Technology (CAST) (China)

Department of Information of National Nature Science Foundation, China (NSFC) (China)

Published by

SPIE

\section{Volume 11904}


The papers in this volume were part of the technical conference cited on the cover and title page. Papers were selected and subject to review by the editors and conference program committee. Some conference presentations may not be available for publication. Additional papers and presentation recordings may be available online in the SPIE Digital Library at SPIEDigitalLibrary.org.

The papers reflect the work and thoughts of the authors and are published herein as submitted. The publisher is not responsible for the validity of the information or for any outcomes resulting from reliance thereon.

Please use the following format to cite material from these proceedings:

Author(s), "Title of Paper," in Plasmonics VI, edited by Zheyu Fang, Takuo Tanaka, Proc. of SPIE 11904 , Seven-digit Article CID Number (DD/MM/YYYY); (DOI URL).

ISSN: 0277-786X

ISSN: 1996-756X (electronic)

ISBN: 9781510646575

ISBN: 9781510646582 (electronic)

Published by

SPIE

P.O. Box 10, Bellingham, Washington 98227-0010 USA

Telephone +1 3606763290 (Pacific Time)

SPIE.org

Copyright (C) 2021 Society of Photo-Optical Instrumentation Engineers (SPIE).

Copying of material in this book for internal or personal use, or for the internal or personal use of specific clients, beyond the fair use provisions granted by the U.S. Copyright Law is authorized by SPIE subject to payment of fees. To obtain permission to use and share articles in this volume, visit Copyright Clearance Center at copyright.com. Other copying for republication, resale, advertising or promotion, or any form of systematic or multiple reproduction of any material in this book is prohibited except with permission in writing from the publisher.

Printed in the United States of America by Curran Associates, Inc., under license from SPIE.

Publication of record for individual papers is online in the SPIE Digital Library.

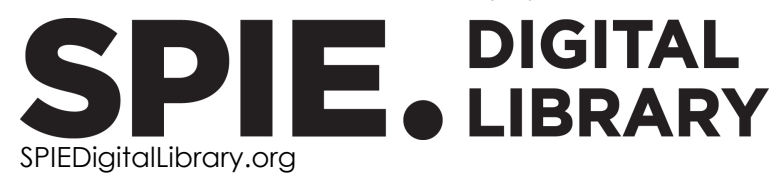

Paper Numbering: A unique citation identifier (CID) number is assigned to each article in the Proceedings of SPIE at the time of publication. Utilization of CIDs allows articles to be fully citable as soon as they are published online, and connects the same identifier to all online and print versions of the publication. SPIE uses a seven-digit CID article numbering system structured as follows:

- The first five digits correspond to the SPIE volume number.

- The last two digits indicate publication order within the volume using a Base 36 numbering system employing both numerals and letters. These two-number sets start with 00, 01, 02, 03, 04, $05,06,07,08,09,0 A, 0 B \ldots$.. OZ, followed by 10-1Z, 20-2Z, etc. The CID Number appears on each page of the manuscript. 


\section{Contents}

LIGHT-MATTER INTERACTION

$1190404 \quad$ Generation of multi-ring perfect vortex beams with tunable intensity distribution (Invited Paper) [11904-3]

\section{OPTOELECTRONICS AND APPLICATIONS}

11904 OU Optimization of metal nanoparticles dimensions for efficient energy harvesting device using localized surface plasmon resonance [1 1904-29]

\section{POSTER SESSION}

11904 OV Polarization-insensitive Fano resonance for highly sensitive terahertz sensors [1 1904-30]

11904 OW Exotic coupling between plasmonic nanoparticles through geometric configurations [11904-31]

$11904 \mathrm{OZ} \quad$ Effect of baseline correction on the quantitative analysis of soil LIBS [11904-34]

$1190411 \quad$ Tunable double Rabi splitting in hybrid plasmonic-J-aggregates-WS 2 nanocavity [11904-36]

1190412 Spatiotemporal imaging of weakly excited femtosecond SPP based on space-dependentquantum channel effect [11904-37]

1190413 Wavelength controllable device for simultaneous generation of surface plasmon polariton Bessel-like beams and bottle beams [1 1904-38]

1190414 Dynamics of localized plasmonic excitation excited by pure propagating surface plasmon source at different positions [11904-39]

1190415 Strong circular dichroism generation in an AU SRR/graphene nanoribbon arrays plasmonic hybrid system [1 1904-40]

1190417 Stabilization three-dimensional refractive-index reconstruction system of single suspension cell [1 1904-42]

11904 1B Space-time adaptive precision imaging and near-field engineering [1 1904-46]

11904 1C Spatial characteristics of spectral intensity of laser induced plasma [11904-47] 
11904 IG Nonlinear optical properties of silver nanoparticles: separating thermo-optical and Kerr effects [11904-51]

$11904 \mathrm{1H}$ The plasmon splitting reflectance spectra on anodized titanium surface in the presence of $\mathrm{Yb}_{2} \mathrm{O}_{3}$ upconversion luminescence [1 1904-52]

$1190411 \quad$ FDTD simulations field on gold nanoparticles and silver nanorods [11904-53]

$119041 \mathrm{~J} \quad$ Optical properties of Cu/Au surfaces structures induced by fs laser exposure with circular polarization [1 1904-54] 